\title{
Achievement Goals and Learning Approaches in the Context of Social Studies Teaching: Comparative Analysis of 3x2 and 2x2 Models
}

\begin{tabular}{|c|c|}
\hline \multicolumn{2}{|c|}{$\begin{array}{c}\text { Servet ÜZTEMUR* } \\
\text { Gaziantep University, Faculty of Nizip Education, Department of Turkish and Social Sciences } \\
\text { Education, ORCID: https://orcid.org/0000-0002-1580-9123 }\end{array}$} \\
\hline Article history & This paper aims to determine the predictive relationships between \\
\hline $\begin{array}{l}\text { Received: } \\
05.01 .2020\end{array}$ & $\begin{array}{l}\text { achievement goals and learning approaches in the context of social } \\
\text { studies teaching and to compare the goal orientation models }(3 \times 2,2 \times 2)\end{array}$ \\
\hline $\begin{array}{l}\text { Received in revised form: } \\
28.02 .2020\end{array}$ & $\begin{array}{l}\text { in the context of their relationships with learning approaches. The study } \\
\text { utilized the multi-factorial predictive correlational design. The study } \\
\text { sample consists of } 259 \text { middle school students, who were selected by }\end{array}$ \\
\hline $\begin{array}{l}\text { Accepted: } \\
28.02 .2020\end{array}$ & $\begin{array}{l}\text { simple random sampling technique, studying in public schools in the } \\
\text { central districts of Manisa, a province in the west of Turkey, in the 2018- }\end{array}$ \\
\hline Key & 2019. academic year. The data were collected by means of "Social \\
\hline $\begin{array}{l}\text { Social studies; } 3 \times 2 \\
\text { achievement goals; } 2 \times 2 \\
\text { achievement goals; learning } \\
\text { approaches; structural equation } \\
\text { model, middle school students }\end{array}$ & $\begin{array}{l}\text { Studies Oriented Achievement Goal Scale" and "Social Studies Learning } \\
\text { Approaches Scale". The study concludes that learning achievement goals } \\
\text { positively predict deep learning approaches but negatively predict surface } \\
\text { learning approaches. Also, performance-goal orientation negatively } \\
\text { predicts deep learning approaches but positively predicts surface learning } \\
\text { approaches. Compared to the } 3 \times 2 \text { model, the } 2 \times 2 \text { achievement goal } \\
\text { model showed a better fit with the data in explaining the relationships } \\
\text { between achievement goals and learning approaches. Findings revealed } \\
\text { the complex structure of achievement goals specific to the subject area. } \\
\text { The results of the research were discussed in the context of the effects of } \\
\text { achievement goals on the learning process. }\end{array}$ \\
\hline
\end{tabular}

\section{Introduction}

The ultimate goal of learning is to achieve success. Students' motivational characteristics affect the learning process in a multidimensional way. Considering the effects of perceptions of and views about achievement on educational outcomes, "Achievement Goal Theory" stands out among the studies that have examined students' motivational characteristics in recent years (Chen, 2001; Dweck \& Leggett, 1988). Achievement goals refer to how students define success, how they interpret success-oriented activities, and what behaviors they adopt to achieve success (Duman \& Eren, 2014). They are students' beliefs about the goals they set for achieving success and their perceptions of why they want to learn (Ames, 1992; Pintrich, 2000). To bring a different perspective to the literature about the goal orientations adopted by students, who are the main actors of the learning process, this study attempted to provide empirical evidence on the relationship between achievement goals and learning approaches in the context of social studies teaching. The first part of the paper

\footnotetext{
* Correspondency: servetuztemur@gmail.com
} 
provides a theoretical framework for achievement goals and learning approaches and examines the relationships between these two variables on the basis of the relevant literature.

\section{Theoretical Framework}

\section{Achievement Goals}

The Achievement Goal Theory is a socio-cognitive theory that attempts to explain students' approach to academic tasks, to what extent they are motivated for these tasks, and the reasons for the behavioral patterns they adopt in performing these tasks (Elliott \& McGregor, 2001; Zhou, Adesope, Winne \& Nesbit, 2019). Early goal theorists contrasted two types of goal orientations: mastery- and performance- goal orientation (Dweck \& Leggett, 1988). Later research categorized performance-goal orientations under two sub-dimensions: "performance-approach" and "performance-avoidance" (Ames, 1992; Elliot \& Harackiewicz, 1996). Mastery-goal orientation encompasses one's attempts to develop competencies and to gain an understanding of or insight into a holistic perspective, without expecting any reward in the learning process (Duman \& Eren, 2014). Students with mastery-oriented goals have intrinsic motivation and strive to improve themselves and acquire new skills (Ames \& Archer, 1988; Rawsthorne \& Elliot, 1999). In addition, rather than turning to the views of external authorities (teachers, parents) and peers, they perform self-assessment according to their own internalized norms so as to determine whether they are sufficient in the learning process (Jagacinski \& Stricland, 2000).

On the other hand, the main goal for the students with performance-approach goals is to perform better than their peers, to be appreciated by their teachers and peers, and to be the most successful student in the classroom (Elliot \& Harackiewicz, 1996). These students are motivated by a desire to prove themselves and compete with their peers (Ozgungor, 2014). Besides, students with performance-avoidance orientation try to avoid risks as much as possible because they do not want to be negatively evaluated by others (Cetin, Ilhan \& Yilmaz, 2014; Vandewalle, 1997). Their main purpose is not to learn but to receive others' approval (Bulus, 2011; Ozgungor, Oral \& Karababa, 2015). They, therefore, tend to avoid situations where they may be perceived as inadequate by others (Finney, Pieper \& Barron, 2004; Middleton \& Midgley, 1997). These students try to pretend capable enough in order to make a positive impression on the people around them. They are frustrated by situations where they are evaluated negatively or in which they fail. As a result, they may try to avoid such situations and leave their work unfinished (Leary \& Kowalski, 1995; Weeks et al., 2009).

Some of the later studies noted that, like performance-goal orientations, mastery-goal orientations should also be categorized under two sub-dimensions as approach and avoidance. Thence the theory was updated as 2x2 (Elliot \& McGregor, 2001; Pintrich, 2000). According to this new $2 \times 2$ model, students' achievement goals are categorized on the basis of competence and discussed in two different dimensions. The first dimension, rooted in the definition of competence, makes a grouping as mastery-performance. On the other hand, the second dimension, rooted in the valence of competence, makes a grouping as approachavoidance (Elliot \& McGregor, 2001; Kadioglu-Akbulut \& Uzuntiryaki-Kondakci, 2019). Accordingly, students with mastery-approach goals tend to finish a given task properly, develop a deep insight into a topic, and achieve maximum knowledge and skills, whereas students with mastery-avoidance goals, as a reflection of their perfectionist personalities, tend to avoid situations in which they might fail to achieve mastery (Elliot \& McGregor, 2001; 
Genc \& Goksu, 2019; Pintrich, Conley \& Kempler, 2003). These students generally aim to be able to retain what is learned and to refrain from making mistakes while studying (Akin, 2006).

In the $2 \times 2$ model, the absolute and self-goals are students' own self-assessments, which are grouped under the learning dimension as they are not influenced by other people's value judgments (Elliot \& McGregor, 2001). Elliot, Murayama, and Pekrun (2011) proposed that absolute and self-goals are separable. The revision of the $2 \times 2$ model yielded the $3 \times 2$ model. Table 1 presents that $3 \times 2$ model (Elliot et al., 2011).

Table 1. 3x2 Achievement Goals Model

\begin{tabular}{lllll}
\hline \multirow{2}{*}{ Valence } & $\begin{array}{l}\text { Absolute } \\
\text { (task) }\end{array}$ & $\begin{array}{l}\text { Interpersonal } \\
\text { (self) }\end{array}$ & $\begin{array}{l}\text { Interpersonal } \\
\text { (other) }\end{array}$ \\
\cline { 2 - 5 } $\begin{array}{l}\text { Positive } \\
\text { sucproaching }\end{array}$ & Task-approach goal & Self-approach goal & $\begin{array}{l}\text { Other-approach } \\
\text { goal }\end{array}$ \\
\cline { 2 - 5 } $\begin{array}{l}\text { Negative } \\
\text { (avoiding } \\
\text { failure) }\end{array}$ & Task-avodiance goal & Self-avodiance goal & $\begin{array}{l}\text { Other-avodiance } \\
\text { goal }\end{array}$ \\
\hline
\end{tabular}

According to Table 1, the definition dimension of competence is divided into three categories as task (absolute), self (core), and interpersonal (other), whilst the valence dimension of competence is divided into two: approaching success and avoiding failure. The resulting new model has the following dimensions: task (absolute)-approach, task-avoidance, self (self)approach, self-avoidance, other (other)-approach, and other-avoidance (Elliot et al., 2011; Kadioglu-Akbulut \& Uzuntiryaki-Kondakci, 2019). Students with task-approach goals give importance to gaining competence, whereas those with task-avoidance goals attach importance to avoiding failure in a given task. Students with self-approach aim to perform better than before and improve their competence, while those with self-avoidance try to eschew failing or performing worse than before. Finally, students with other-approach aim to perform better than their peers, while those with other-avoidance try to abstain from performing worse than their peers (Kadioglu-Akbulut \& Uzuntiryaki-Kondakci, 2019).

A thorough search of the relevant literature showed that achievement goals are positively correlated with active participation in classes (Duman \& Eren, 2014), grit (Akın, \& Arslan, 2014), high academic achievement (Green \& Miller, 1996), effort (Tuominen, Aro \& Niemivirta, 2008), and self-efficacy (Chan, 2008; Middleton \& Midgley, 1997). Additionally, high academic achievement, effort, intrinsic motivation, intrinsic locus of control, and persistence were reported to be positively correlated with performance-approach orientation but negatively correlated with performance-avoidance orientation (Arslan \& Akın, 2015; Elliot, 1999; Elliot \& Harackiewicz, 1996).

\section{Learning Approaches}

Learning approaches can be defined as the motives a student has or the methods he/she chooses when undertaking a specific learning task (Entwistle \& McCune, 2004). The review of the relevant literature reveals that learning approaches are classified as deep learning and surface learning approaches (Martön \& Soljö, 1976; Ramsden, 2003).

A deep approach to learning refers to the effort to integrate the new information with the previous information and to create meaning in the learning process. A student who adopts this 
learning approach seeks to understand the meaning; thus, the new information can be transferred to new situations very easily. Students who are able to transfer their knowledge to daily life are intrinsically motivated and can approach new situations critically. Instead of passing their exams in short-term, they aim to achieve permanent learning in longer-term (Cano, 2005; Houghton, 2004).

Students with a surface approach to learning, on the other hand, are motived by external factors. Thusly, these students are more concerned with repetition and memorization than understanding the meaning. Their goal is not to achieve internal satisfaction but to satisfy external expectations. To that end, they easily forget the information they have learned in the long run. Even if high-level cognitive skills are needed, they try to finish the job with minimum effort. Their main goal is to get a high score from their tests (Biggs, 1999; Prosser \& Trigwell, 1999).

An examination of the relevant literature indicates that learning approaches have significant relationships with variables such as academic achievement (Mayya, Rao \& Ramnarayan, 2004; Rodríguez \& Cano, 2006), epistemological beliefs (Chan, 2003; Üztemur, Dinç \& Acun, 2020), length of studying for a course/exam (B1yıkl1, 2016), and academic risk-taking (Üztemur et al., 2020). Given that, it can be articulated that students who adopt a deep approach to learning have higher academic achievement and more sophisticated epistemological beliefs, study more, and are more willing to take academic risks than those who adopt a surface approach to learning. It is also emphasized that learning approaches are highly influenced by the structure of the course content, how the teacher teaches, the characteristics of the learning environment, and the preferred measurement and evaluation techniques. Thereupon, the learning approaches adopted by students throughout the learning process may vary (Cuthbert, 2005; Ekinci, 2009) with respect to different parametres.

\section{Relationships between Achievement Goals and Learning Approaches}

Students with mastery-goal orientation prefer deep cognitive strategies in the learning process and endeavor to create meaningful learning. Thinking that the ability to learn is not innate, they believe that effort and persistence are important in the learning process (Buluş, 2011; Seifert, 1995). Similarly, students who adopt a deep learning approach make their learning meaningful not through memorizing and are very good at transferring their newlyacquired knowledge and skills to novel situations (Felder \& Brent, 2005). Related studies have emphasized that mastery-goal orientation and deep learning approaches are related to intrinsic motivation for learning (Cano, 2005; Cano \& Berben, 2009; Heyman \& Dweck, 1992). Hence, intrinsic motivation is what drives a student who adopts learning goal orientation to learn about a subject. Such a student aims to learn a subject in-depth and from a holistic perspective. Akin to that, students who adopt a deep learning approach are triggered by their individual interests and aspirations rather than external pressure or extrinsic motivation when learning (Beckwith, 1991; Middleton \& Midgley, 1997). A review of the relevant literature demonstrates a positive relationship between mastery-goal orientation and deep learning approaches (Ames \& Archer, 1988; Duman \& Eren, 2014; Ho \& Hau, 2008; Vrugt \& Oort, 2008). Besides, both mastery-goal orientation and deep learning approaches were reported to be positively correlated with academic achievement (Biggs, Kember \& Leung, 2001; Green \& Miller, 1996).

Students who adopt a surface learning approach, on the other hand, are triggered by external reinforcements instead of intrinsic motivation when learning a subject. They are inclined to 
make the least cognitive effort when learning a subject. For them, it is essential to reach a goal as soon as possible and in the shortest possible way. Whence, it is more important for them to get higher grades than to develop insight with a deep and holistic understanding. They use the memorization method a lot in the learning process and seek to make less cognitive efforts (Ramsden, 2003). Likewise, students with performance-goal orientation mostly adopt surface learning strategies to learning (Ames \& Archer, 1988; Duman \& Eren, 2014; Ho \& Hau, 2008). They attribute the reasons for being successful to innate intelligence and abilities rather than effort and perseverance. When they face a difficult problem, they give up immediately. Their self-confidence is low, and they intend to achieve success with little effort (Bulus, 2011; Dinç \& Üztemur, 2017; Dweck \& Leggett, 1988; Limpo \& Alves, 2017). It has been reported that performance-goal orientation and the surface learning approach are associated with extrinsic motivation (Agbuga, 2014; Cano \& Berben, 2009; Heyman \& Dweck, 1992). Students with performance-goal orientation are not stimulated by intrinsic sources of motivation. On the contrary, external sources of motivation viz. high grades, being the best in the classroom motivate these students. When external sources of motivation are not present, these students are usually not curious about a topic and are not eager to dwell upon it. As a result, prior to tests, they often study the topics that are likely to be covered in the test and pay no attention to the other topics (Ames, 1992; Elliot, McGregor \& Gable, 1999; Diseth \& Kobbeltvedt, 2010).

Although achievement goals and learning approaches affect students' perception and behavior patterns related to the learning process and are, theoretically, fed by the same motivational source, very few studies have been conducted to empirically examine the relationship between these two variables (Cano \& Berben, 2009; Leenknecht, Hompus \& Schaaf, 2019). Cano and Berben (2009) concluded that there are moderate significant relationships between university students' achievement goals and learning approaches in the context of mathematics teaching, and these two structures are intertwined. In similar fashion, a study conducted by Leenknecht et al. (2019) with university students found that students with mastery-goal orientation are more likely to use deep learning approaches. Together with that, findings reported by various studies (Elliot et al., 1999; Elliot \& McGregor, 2001) can be interpreted in that way; mastery-goal orientation and performance-avoidance goal orientation are significant predictors of deep learning approaches and surface learning approaches, respectively. What is more, the relevant literature includes studies which indicated that performance-approach goal orientation is positively correlated with high academic achievement and cognitive strategies (Bulus, 2011; Church, Elliot \& Gable, 2001; Elliot \& Church, 1997; Pintrich, 2000; Wolters, $\mathrm{Yu} \&$ Pintrich, 1996) as well as with surface learning strategies (Midgley, Middleton \& Kaplan, 2001). In light of these results it is highly difficult to announce that performance-goal orientation is a completely undesirable behavior pattern in the learning process. For example, a student can compete with other students in a social studies class and work hard to be the best in the class. It is not intrinsic motivation that motivates this student to be successful in the class, but rather to get the approval of his/her social environment and to perform better than his/her friends. That being the case, it is difficult to claim that the performance-approach goal orientation is completely undesirable, especially in education systems where high scores obtained in central exams are considered as success criteria. Furthermore, there are studies indicating that surface learning strategies are not significantly correlated with both performance-approach and performance-avoidance goal orientations (Archer, 1994; Duman \& Eren, 2014). These studies declared that students exhibit mastery-approach and performanceapproach goal orientations in a simultaneous manner (Green \& Miller, 1996). All these results display that the sub-dimensions of achievement goals, which cannot be clearly separated from each other, have a rather complex structure. Along with these, how the structural components 
of achievement goals with different properties $(3 \times 2,2 \times 2)$ are correlated with learning approaches in the context of Turkish culture is still a matter of interest. Taking these as a starting point, the general purpose of this study is to determine whether middle school students' achievement goals significantly predict their learning approaches in the context of the social studies course. To this end, answers to the following questions were sought:

- What is the level of students' social studies-oriented achievement goals and learning approaches?

- How are the social studies-oriented achievement goals and the sub-dimensions of learning approaches correlated?

- Which achievement goals orientation model $(3 \times 2$ or $2 \times 2)$ better explains the relationship between students' social studies-oriented achievement goals and learning approaches?

\section{Methods}

\section{Research Design}

This research used the multi-factorial predictive correlational design to reveal the structural relationships between middle school students' social studies-oriented achievement goals and learning approaches. The predictive correlational design is used to be able to predict a dependent variable by means of an independent variable. Should there be more than one predictor variable, the multi-factorial predictive correlational design is used (Fraenkel, Wallen \& Hyun, 2012). In this study, social studies-oriented achievement goals were assigned as the predictor variable and learning approaches as the predicted variable. This was iterated for both $3 \times 2$ achievement goals and $2 \times 2$ achievement goals models. Alongside this, the fitness of the theoretical models established by structural equation modeling (SEM) with the available data was tested, and these models were compared with each other.

\section{Population and Sample}

The study population consists of middle school students in Yunusemre and Şehzadeler districts of Manisa, a province in the West of Turkey. The study was conducted with 259 students studying in five public middle schools, who were selected by the simple random sampling technique. The data were collected in April and May 2019. Table 2 presents the demographic characteristics of the students.

Table 2. Personal information of the participants

\begin{tabular}{llll}
\hline Variable & Category & $\begin{array}{l}\text { Frequency } \\
\text { f }\end{array}$ & $\begin{array}{l}\text { Percentage } \\
\mathbf{\%}\end{array}$ \\
\hline \multirow{2}{*}{ Gender } & Male & 120 & 46.3 \\
& Female & 139 & 53.7 \\
\hline \multirow{2}{*}{ Graduation (Father) } & Uneducated & 4 & 1.5 \\
& Primary & 64 & 24.7 \\
& Middle & 55 & 21.2 \\
& High School & 103 & 39.8 \\
& Graduate and Postgraduate & 33 & 12.7 \\
\hline \multirow{3}{*}{ Graduation (Mother) } & Uneducated & 7 & 2.7 \\
& Primary & 93 & 35.9 \\
& Middle & 88 & 34 \\
& High School & 54 & 20.8 \\
\hline
\end{tabular}




\begin{tabular}{llll}
\hline & Fifth & 57 & 22 \\
Class Level & Sixth & 74 & 28.6 \\
& Seventh & 54 & 20.8 \\
& Eighth & 74 & 28.6 \\
\hline
\end{tabular}

It can be inferred from Table 2 that the participants are equally distributed in terms of their sex and grades. When the educational background of the parents of the participants is examined, it can be stated that the number of students whose parents are illiterate and university graduates is less than the others.

\section{Data Collection Tools}

This section contains information about the data collection tools used in the research.

\section{Social Studies Oriented Achievement Goal Scale}

With a view to measuring middle school students' social studies-oriented achievement goals, we referred to the "Social Studies Oriented Achievement Goal Scale" developed by Gezer and Şahin (2016) based on the $3 \times 2$ model. As a result of the exploratory factor analysis (EFA) and confirmatory factor analysis (CFA), the scale has a total of 29 items and six dimensions: self-approach (6 items), self-avoidance (5 items), task-approach (4 items), taskavoidance (4 items), other-approach (5 items), and other-avoidance (5 items). The alpha internal consistency coefficients of the sub-dimensions were $.73, .70, .63, .55, .71$ and .73 , respectively. The high scores obtained from the dimensions of the five-point Likert type scale ( 1 =strongly disagree, 5=strongly agree) exhibit that dimension is adopted more (Gezer \& Şahin, 2016).

CFA was applied to the scale, and the construct of the original six-factor scale, which was developed by Gezer and Şahin (2016), was tested with the available data. One item from each of the self-approach, self-avoidance, and other-avoidance dimensions was removed from the data set because their factor loadings were lower than .32. As a result of the repeated CFA, the original six-factor construct of the scale was maintained, and the fit indices were acceptable $(\chi 2=561.584, \mathrm{df}=284, \mathrm{p}<.01, \chi 2 / \mathrm{df}=1.977, \mathrm{AGFI}=.83, \mathrm{RMSEA}=.06, \mathrm{IFI}=.88$, $\mathrm{GFI}=.86, \mathrm{CFI}=.88$ ). Alpha internal consistency coefficients obtained in this study were .77 , $.76, .70, .67, .75$, and .81 for self-approach, self-avoidance, task-approach, task-avoidance, other-approach, and other-avoidance, respectively.

\section{Social Studies Learning Approaches Scale}

To measure middle school students' social studies-oriented learning approaches, we utilized the "Social Studies Learning Approaches Scale" developed by Gezer and Sahin (2017). As a result of EFA and CFA, the scale consisted of surface learning (11 items) and deep learning (13 items) factors. The high scores obtained from the dimensions of the fivepoint Likert type scale $(1=$ strongly disagree, $5=$ strongly agree) indicate that dimension is adopted more. The alpha internal consistency coefficients were .79 for surface learning and .87 for deep learning (Gezer \& Şahin, 2017).

CFA was applied to the scale, and the construct of the original two-factor scale, which was developed by Gezer and Şahin (2017), was tested with the available data. Three items from surface learning and one item from deep learning were removed as their factor loadings were lower than .32 . As a result of the repeated CFA, the original six-factor construct of the scale was maintained, and the fit indices were acceptable $(\chi 2=289.626, \mathrm{df}=168, \mathrm{p}<.01, \chi 2 / \mathrm{df}=$ 
$1.724, \mathrm{AGFI}=.86, \mathrm{RMSEA}=.06, \mathrm{IFI}=.90, \mathrm{GFI}=.89, \mathrm{CFI}=.90)$. The alpha internal consistency coefficients obtained in this study were .75 and .80 for surface learning and deep learning, respectively.

\section{Data Analysis}

SPSS program was used to measure the correlations between descriptive analyses and variables. With the aim of preparing the data for analysis, normality test and missing value analysis were performed for each variable. There were no missing values for both scales, and the data were normally distributed. Prior to the analyses, it was checked whether there was a common method bias problem. Common method bias, also known as common method variance, is a measurement error resulting from similar responses as a result of applying the structures to be measured to the same people at the same time in a single questionnaire form (Podsakoff, Mackenzie, Podsakoff \& Lee, 2003). The two scales used in this study were merged under a single data collection form. To determine whether this led to a common method bias, Harman's single factor test was applied to 53 items contained in both scales. If the variance of the first factor before rotation is less than $40 \%$, it is interpreted that there is no common method bias (Malhotra, Kim \& Patil, 2006; Podsakoff et al., 2003). As a result of the unrotated principal component factor analysis, a total of 13 factors with eigenvalues greater than 1 were obtained. As the variance of the first factor was $17.65 \%$ in the data set where $61.37 \%$ of the total variance was explained, it was determined that there was no common method bias problem in the data set (Podsakoff et al., 2003).

With an eye to checking that each item meets the normality assumption when performing CFA in the AMOS program, it was checked whether the kurtosis and skewness values were within \pm 2 ranges (Tabachnick \& Fidell, 2013; Trochim \& Donnelly, 2006). To test the fitness of the theoretical model with the data, the AMOS program and the path analysis consisting of the measurement model and the structural model were used. For the fit of the CFA and SEM models, the root mean square error of approximation (RMSEA), the chi-square value divided by the degree of freedom $(\chi 2 / \mathrm{df})$, the general fit index (GFI), adjusted goodness of fit index (AGFI), the comparative fit index (CFI), and the incremental fit index (IFI) values were taken as criteria (Schumacker \& Lomax, 2010). The reference values of the fit indices are presented in Table 5 in the findings section. To compare the fit levels of $3 \times 2$ and $2 \times 2$ models with the learning approaches, the significance of the chi-square difference test ( $\chi 2$ difference test) and fit indices were examined.

\section{Findings and Results}

Table 3 presents descriptive statistics and correlation values for the sub-dimensions of social studies-oriented achievement goals and learning approaches.

Table 3. Descriptive statistics and correlation coefficients (N:259)

\begin{tabular}{lllllllllll}
\hline Variable & $\bar{X}$ & $\mathbf{S}$ & $\mathbf{1}$ & $\mathbf{2}$ & $\mathbf{3}$ & $\mathbf{4}$ & $\mathbf{5}$ & $\mathbf{6}$ & $\mathbf{7}$ & $\mathbf{8}$ \\
\hline Self-Approach & 4.10 & .79 & 1 & & & & & & & \\
Self-Avoidance & 3.51 & .98 & $.215^{* *}$ & 1 & & & & & \\
Task-Approach & 4.58 & .59 & $.502^{* *}$ & $.172^{* *}$ & 1 & & & & \\
Task-Avoidance & 4.07 & .96 & $.431^{* *}$ & $.390^{* *}$ & $.408^{* *}$ & 1 & & & \\
Other-Approach & 2.95 & .98 & $-.224^{* *}$ & .050 & -.106 & $-.162^{* *}$ & 1 & & \\
Other-Avoidance & 3.46 & .97 & $-.127^{*}$ & $.352^{* *}$ & -.013 & .077 & $.382^{* *}$ & 1 & & \\
Deep Learning & 3.70 & .66 & $.685^{* *}$ & $.123^{* *}$ & $.381^{* *}$ & $.465^{* *}$ & $-.291^{* *}$ & $-.199^{* *}$ & 1 & \\
Surface Learning & 2.04 & .74 & $-.546^{* *}$ & -.002 & $-.288^{* *}$ & $-.330^{* *}$ & $.414^{* *}$ & $.318^{* *}$ & $-.622^{* *}$ & 1 \\
\hline
\end{tabular}

$* *=\mathrm{p}<0.01 *=\mathrm{p}<0.05$ 
It can be inferred from Table 3 that there are insignificant negative relationships between achievement goals (self and task) and performance-goal orientation (other-approach, otheravoidance). Deep learning approaches have a moderate positive relationship with masterygoal orientation and a moderate negative relationship with performance-goal orientation. In contrast, surface learning approaches posses a moderate negative relationship with masterygoal orientation and a moderate positive relationship with performance-goal orientation. It is witnessed that students adopt deep learning approaches and mastery-goal orientation more frequently in social studies classes. Amid all the sub-dimensions, there is no correlation with a value higher than .70. Further to these, the variance inflation factor (VIF) value was less than 10, and tolerance values were greater than .20 (Licht, 1995). These findings denote that there is no multicollinearity problem among the sub-dimensions.

Aiming to reveal whether middle school students' social studies-oriented achievement goals significantly predict their learning approaches, individual studies were conducted for both achievement goals models ( $3 \times 2$ and $2 \times 2)$, and the results were compared.

\section{Study 1 (3x2 Achievement Goals Model-Learning Approaches)}

The theoretical model explaining the relationship between middle school students' $3 \times 2$ achievement goals and their learning approaches was put forward, and the following hypotheses were tested:

- H1: Self achievement goals positively predict deep learning approaches.

- H2: Task achievement goals positively predict deep learning approaches.

- H3: Other achievement goals negatively predict deep learning approaches.

- H4: Self achievement goals negatively predict surface learning approaches.

- H5: Task achievement goals negatively predict surface learning approaches.

- H6: Other achievement goals positively predict surface learning approaches.

Figure 1 presents the SEM analysis performed to demonstrate the adequacy of the theoretical model suggesting the relationship between middle school students' $3 \times 2$ achievement goals and their learning approaches.

As can be observed in Figure 1, the $\mathrm{H} 3$ hypothesis related to the relationship between other achievement goals and deep learning approaches and the H5 hypothesis related to the relationship between task achievement goals and surface learning approaches were removed from the model because their $\mathrm{t}$ values were not significant $(\mathrm{p}>.05)$. Table 4 presents the $\mathrm{t}-$ value, standardized regression coefficients, explained variance, standard error, and significance values for the relevant variables. 


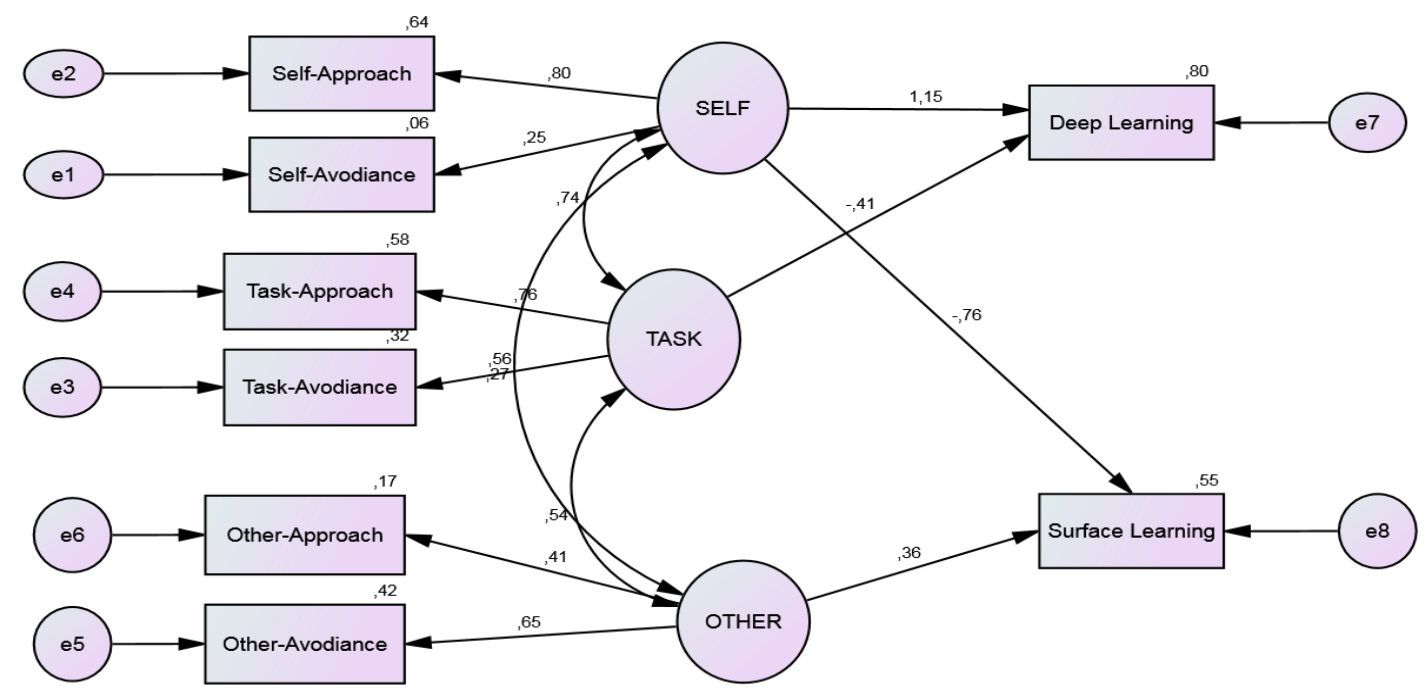

Figure 1. SEM model for the relationships between $3 \times 2$ achievement goals and learning approaches

Table 4. SEM analysis (3x2 achievement goals and learning approaches) results

\begin{tabular}{lllllll}
\hline Hypothesis & $\begin{array}{l}\text { Predictive Variable } \rightarrow \\
\text { Predicted Variable }\end{array}$ & SPC & t-value & SE & $\begin{array}{l}\text { Explained } \\
\text { Variance }\end{array}$ & Result \\
\hline H1 & SELF $\rightarrow$ DEEP & 1.15 & $8.056^{*}$ & .095 & & Supported \\
H2 & TASK $\rightarrow$ DEEP & .40 & $2.758^{*}$ & .098 & .801 & Supported \\
H3 & OTHER $\rightarrow$ DEEP & -.03 & -.269 & .085 & & Not Supported \\
H4 & SELF $\rightarrow$ SURFACE & -.88 & $-7.338^{*}$ & .090 & & Supported \\
H5 & SELF $\rightarrow$ SURFACE & .22 & 1.539 & .112 & .552 & Not Supported \\
H6 & OTHER $\rightarrow$ SURFACE & .35 & $4.346^{*}$ & .061 & & Supported \\
\hline
\end{tabular}

$* *=p<.01, *=p<.05$ (SPC: Standardised Path Coefficient, SE: Standard Error)

It can be inferred from Table 4 that self-achievement goals positively predict deep learning approaches $(\beta=.1 .15)$ and negatively predict surface learning approaches $(\beta=-.88)(p<.01)$. These findings confirmed $\mathrm{H} 1$ and $\mathrm{H} 4$. Task achievement goals significantly and positively predicted deep learning approaches $(\beta=.40)$; thus, the $\mathrm{H} 2$ hypothesis was confirmed. Having said that we were unable to confirm the $\mathrm{H} 3$ (Other achievement goals negatively predict deep learning approaches) and the H5 (Task achievement goals negatively predict surface learning approaches) ( $p>.05)$. Other achievement goals positively predicted surface learning approaches; thus, the H6 was confirmed $(\beta=.35)$. Resultantly, self and task achievement goals represent $80 \%$ of the change in deep learning approaches. Together self and other achievement goals explain 55\% variance of surface learning approaches assigned as the predicted variable. Table 5 presents the values of the fit indices used to determine the adequacy of the $3 \times 2$ model and the fit values of the model.

Table 5. Fit values of the fit indices* and fit values of the $3 \times 2$ model

\begin{tabular}{lllll}
\hline $\begin{array}{l}\text { Fit } \\
\text { Indexes }\end{array}$ & $\begin{array}{l}\text { Perfect } \\
\text { Correspondence } \\
\text { Criteria }\end{array}$ & $\begin{array}{l}\text { Acceptable } \\
\text { Correspondence } \\
\text { Criteria }\end{array}$ & $\begin{array}{l}\text { Model's } \\
\text { Fit Indexes }\end{array}$ & Result \\
\hline$\chi 2 /$ sd & $0 \leq \chi 2 / \mathrm{df} \leq 2$ & $2 \leq \chi 2 / \mathrm{df} \leq 5$ & 10.17 & Not Correspondence \\
RMSEA & $.00 \leq \mathrm{RMSEA} \leq .05$ & $.05 \leq \mathrm{RMSEA} \leq .08$ & .19 & Not Correspondence \\
CFI & $.95 \leq \mathrm{CFI} \leq 1.00$ & $.90 \leq \mathrm{CFI} \leq .95$ & .77 & Not Correspondence \\
GFI & $.95 \leq \mathrm{NFI} \leq 1.00$ & $.90 \leq \mathrm{NFI} \leq .95$ & .87 & Not Correspondence \\
AGFI & $.95 \leq \mathrm{NNFI} \leq 1.00$ & $.85 \leq \mathrm{NNFI} \leq .90$ & .70 & Not Correspondence \\
IFI & $.95 \leq \mathrm{IFI} \leq 1.00$ & $.90 \leq \mathrm{IFI} \leq .95$ & .78 & Not Correspondence \\
\hline
\end{tabular}

*Schumacker \& Lomax, 2010 
According to Table 5, the tested theoretical model does not fit the data set, and the fit indices of the model are not acceptable. According to these findings, it can be said that the $3 \times 2$ model is insufficient in explaining the relationship between achievement goals and learning approaches.

\section{Study 2 (2x2 Achievement Goals Model-Learning Approaches)}

Intending to construct middle school students' social goals-oriented achievement goals in the $2 \times 2$ model, we combined the self and task achievement goals in the scale developed by Gezer and Şahin (2016). In that case, the construct of the scale resulted in mastery-approach, mastery-avoidance, performance-approach, and performance-avoidance. As a result of the CFA, one item from each of mastery-approach, mastery-avoidance, and performanceavoidance dimensions was removed from the analysis for their factor loadings were lower than .32. The results of the repeated CFA showed that the scale fit the $2 \times 2$ model, and the fit indices were acceptable $(\chi 2=561.584, \mathrm{df}=284, \mathrm{p}<.01, \chi 2 / \mathrm{df}=1.977, \mathrm{AGFI}=.83, \mathrm{RMSEA}=$ $.06, \mathrm{IFI}=.88, \mathrm{GFI}=.86, \mathrm{CFI}=.88$ ). The theoretical model explaining the relationship between $2 \times 2$ achievement goals and learning approaches was put forward, and the following hypotheses were tested:

- H7: Mastery-goal orientation positively predicts deep learning.

- H8: Performance-goal orientation negatively predicts deep learning.

- H9: Mastery-goal orientation negatively predicts surface learning.

- H10: Performance-goal orientation positively predicts surface learning.

Figure 2 presents the SEM analysis performed to demonstrate the adequacy of the theoretical model suggesting the relationship between $2 \times 2$ achievement goals and learning approaches.

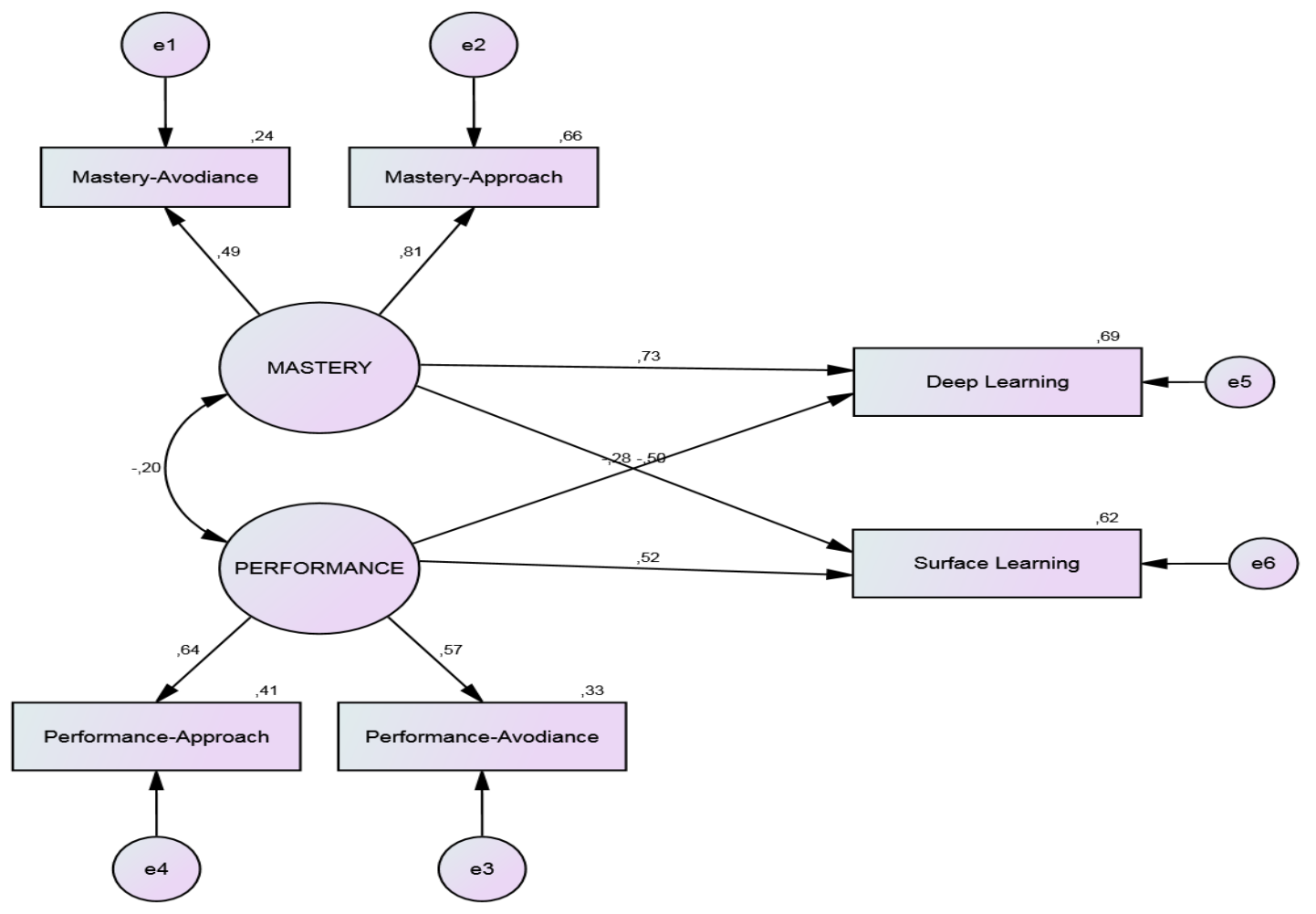

Figure 2. SEM model for the relationships between $2 \times 2$ achievement goals and learning approaches 
Table 6 presents the t-value, standardized regression coefficients, explained variance, standard error, and significance values for the variables shown in Figure 2.

Table 6. SEM analysis (2x2 achievement goals and learning approaches) results

\begin{tabular}{lllllll}
\hline Hyp. & $\begin{array}{l}\text { Predictive } \begin{array}{c}\text { Variable } \rightarrow \\
\text { Predicted Variable }\end{array} \\
\text { SPC }\end{array}$ & t-value & SE & $\begin{array}{l}\text { Explained } \\
\text { Variance }\end{array}$ & Result \\
\hline H7 & Mastery $\rightarrow$ Deep & .72 & $11.400^{*}$ & .038 & .69 & Supported \\
H8 & Performance $\rightarrow$ Deep & -.27 & $-.4 .079^{*}$ & .045 & & Supported \\
H9 & Mastery $\rightarrow$ Surface & -.49 & $-7.676^{*}$ & .048 & .62 & Supported \\
H10 & Performance $\rightarrow$ Surface & .52 & $7.248^{*}$ & .053 & & Supported \\
\hline
\end{tabular}

$* *=\mathrm{p}<.01, *=\mathrm{p}<.05$ (SPC: Standardised Path Coefficient, SE: Standard Error)

It can be inferred from Table 6 that mastery-goal orientation positively predicts deep learning approaches $(\beta=.72)$ and negatively predicts surface learning approaches $(\beta=.49)(p<.001)$. These findings confirmed the $\mathrm{H} 7$ and $\mathrm{H} 9$ hypotheses. Performance-goal orientation negatively predicted deep learning approaches $(\beta=-.27)$ and positively predicted surface learning approaches $(\beta=.52)$. These findings confirmed the H8 and H10 hypotheses $(p<.001)$. On the grounds of this, achievement goals represented $69 \%$ and $62 \%$ of the changes in deep and surface learning approaches, respectively. Table 7 presents the values of the fit indices used to determine the adequacy of the $2 \times 2$ model and the fit values of the model.

Table 7. Fit values of the fit indices* and fit values of the $2 \times 2$ model

\begin{tabular}{|c|c|c|c|c|}
\hline $\begin{array}{l}\text { Fit } \\
\text { Indexes }\end{array}$ & $\begin{array}{l}\text { Perfect } \\
\text { Correspondence } \\
\text { Criteria }\end{array}$ & $\begin{array}{l}\text { Acceptable } \\
\text { Correspondence } \\
\text { Criteria }\end{array}$ & $\begin{array}{l}\text { Model's } \\
\text { Fit } \\
\text { Indexes }\end{array}$ & Result \\
\hline $\begin{array}{l}\chi^{2 / d f} \\
\text { RMSEA }\end{array}$ & $\begin{array}{l}0 \leq \chi^{2} / \mathrm{df} \leq 2 \\
.00 \leq \mathrm{RMSEA} \leq .05\end{array}$ & $\begin{array}{l}2 \leq \chi^{2} / \mathrm{df} \leq 5 \\
.05 \leq \mathrm{RMSEA} \leq .08\end{array}$ & $\begin{array}{l}7.069 \\
.098\end{array}$ & $\begin{array}{l}\text { Not Correspondence } \\
\text { Not Correspondence }\end{array}$ \\
\hline CFI & $.95 \leq \mathrm{CFI} \leq 1.00$ & $.90 \leq \mathrm{CFI} \leq .95$ & .92 & $\begin{array}{l}\text { Acceptable } \\
\text { Correspondence }\end{array}$ \\
\hline GFI & $.95 \leq \mathrm{NFI} \leq 1.00$ & $.90 \leq \mathrm{NFI} \leq .95$ & .96 & Perfect Correspondence \\
\hline AGFI & $.95 \leq \mathrm{NNFI} \leq 1.00$ & $.85 \leq \mathrm{NNFI} \leq .90$ & .86 & $\begin{array}{l}\text { Acceptable } \\
\text { Correspondence }\end{array}$ \\
\hline IFI & $.95 \leq \mathrm{IFI} \leq 1.00$ & $.90 \leq \mathrm{IFI} \leq .95$ & .92 & $\begin{array}{l}\text { Acceptable } \\
\text { Correspondence }\end{array}$ \\
\hline
\end{tabular}

As per Table 7, except for the chi-square value divided by the degree of freedom and the RMSEA value, all the other fit indices were found to be excellent and acceptable. Thereby, we can say that the $2 \times 2$ model partially fits the data set.

The chi-square difference test ( $\chi 2$ difference test) was performed to determine which model fits better in explaining the relationship between achievement goals and learning approaches (Tabachnick \& Fidell, 2013: 726). Looking at the chi-square difference test, the $2 \times 2$ model fits the data better than the $3 \times 2$ model $[\chi 2$ difference $(9, \mathrm{~N}=259)=110.15, p<.001]$. Moreover, when the fit indices were compared, it was determined that the values of the $2 \times 2$ model were better than those of the $3 \times 2$ model.

\section{Discussion}

The results obtained in the present study, which aimed to explain the predictive and correlational relationships between achievement goals and learning approaches in the context of social studies course, proclaimed that the theoretical model is supported by the data. On that account, mastery-goal orientation positively predicted deep learning approaches and 
negatively predicted surface learning approaches. What is more, performance-goal orientation negatively predicted deep learning approaches and positively predicted surface learning approaches. These results are consistent with the results of empirical studies conducted in different fields (mathematics) and with differing samples (university students) in the relevant literature (Cano \& Berben, 2009; Leenknecht et al., 2019). Students' achievement goals are their behavior patterns and, in a way, constitute roadmaps in the learning process. This has a direct impact on learning approaches. It has been reported that intrinsically motivated students who intend to make efforts in the learning process and want to learn a subject not because of external expectations but because they are really curious, adopt the deep learning approach and use metacognitive strategies more, have high levels of academic achievements and selfefficacy, and have more epistemological beliefs (Goncalves, Niemivirta \& Lemos, 2017; Limpo \& Alves, 2017; Matos, Lens \& Vansteenkiste, 2007; Zhou et al., 2019). Contrarily, students with performance-goal orientation, who place a greater emphasis on competition in the learning process and aspire to meet external expectations, to prove themselves, or to avoid situations in which they perform worse than their peers, adopt surface learning approaches, use the memorization technique, and experience test anxiety more often (Diseth \& Kobbeltvedt, 2010; Elliot et al., 1999). According to the results of the research given above, it can be underlined that achievement goals form cognitive and affective learning patterns and are important factors that impact students' behaviours in the learning process (Limpo \& Alves, 2017).

Another result of the present study is that the $2 \times 2$ model yielded better results than the $3 \times 2$ model in explaining the relationship between achievement goals and learning approaches. These results both reveal the complex nature of middle school students' social studiesoriented achievement goals and prove that the students cannot distinguish between self and task achievement goals. This result is not specific to Turkish culture or to the social studies course. In fact, many studies so far have reported that achievement goals are interwoven, making it very difficult to assure a clear distinction between their sub-components, and that students would adopt multiple achievement goals at the same time as a reflection of this situation (Cano \& Berben, 2009; Blankert \& Hamstra, 2017; Goncalves et al., 2017; Senko, Hulleman \& Harackiewicz, 2011; Zhou et al., 2019). It has also been suggested that mastery and performance-goal orientation can be adopted concurrently, and mastery-approach and performance-approach can be considered as the "approach" goal orientation (Bulus, 2011; Gutman, 2005; Senko et al., 2011; Zhou et al., 2019). Studies suggesting that performanceapproach orientation is positively correlated with intrinsic motivation, self-efficacy, cognitive strategies, and academic achievement can here be underpinned as evidence (Elliot \& Harackiewicz, 1996; Church et al., 2001; Wolters et al., 1996). According to these results, it would not be right to perceive performance-approach goal orientation as a negative goal orientation. Particularly in the Turkish education system, where test anxiety is felt at a very young age and academic achievement means getting high grades, it is an expected result that extrinsically motivated students attribute importance to competition and adopt performanceapproach orientation as a result. This can be ignited further when teachers, in lieu of creating a cooperative learning environment, build a competitive classroom environment that emphasizes students' individual differences.

\section{Implications Limitations, and Future Direction}

Achievement goals are behaviour patterns that specify how students will approach learning. In an ideal learning setting, students are expected to adopt mastery-goal orientation. In this way, they will abandon rote learning and develop a holistic perspective to learning. In 
this respect, it is important that mastery-approach goal orientation has a high level of relationship with deep learning approaches. Students' achievement goals and learning approaches are influenced by the school environment in general, and the classroom environment in particular (Ames \& Ames, 1981; Bulus, 2011; Duman \& Eren, 2014; Kaplan \& Maehr, 1999). How teachers approach their students is particularly important. Students taught by teachers who pinpoint that knowledge changes according to place, time, and context, who draw attention to the fact that the real success originates from intrinsic motivation, and who encourage cooperation not competition among students will probably adopt mastery-goal orientation and deep learning approaches. Students who are not compared with their peers in the classroom and whose personal development is prioritized in the process will own increased self-confidence and self-esteem and on the grounds of this will adopt a mastery-approach goal orientation. In a classroom environment with just the opposite conditions, students are likely to feel inadequate and develop a negative belief that they will never improve their skills.

No study has been conducted so far to examine the relationship between achievement goals and learning approaches in the context of social studies teaching, which makes this study more valuable. The results we have obtained are important in that they extend the scope of the achievement goals' effects on the learning process. Having said that, this study also has its own limitations. We used self-report questionnaires to measure middle school students' achievement goals and learning approaches. We do not precisely know what behaviours the relevant variables correspond to in the learning environment. To overcome this, observational studies can be performed in classrooms. Plus, how teachers' behaviour patterns act on students' achievement goals and learning approaches still remains a question. Future research can deal with this question. Added to that, for to make the relationships between achievement goals and learning approaches more apparent, similar studies can be conducted with samples from different cultures. Finally, in this study, we compared the achievement goals models ( $3 \times 2$ or $2 \times 2)$ in the context of learning approaches. Future research to be carried out can compare the achievement goals models in terms of their relationships with different variables.

\section{References}

Agbuga, B. (2014). Validity and reliability of $3 \times 2$ achievement goal model scale in Turkish undergraduate students. Hacettepe Journal of Sport Sciences, 25(3), 109-117.

Akin, A. (2006). The validity and reliability study of $2 \times 2$ achievement goal orientations scale. Sakarya University Journal of Faculty of Education, 12, 1-13.

Akin, A. \& Arslan, S. (2014). The relationships between achievement goal orientations and grit. Educatian and Science, 39(175), 267-274.

Arslan, S. \& Akin, A. (2015). The validity and reliability study of $2 \times 2$ achievement goal orientations scale (revised form). Sakarya University Journal of Education, 5(1), 7-15.

Ames, C., (1992). Classrooms: Goals, structures, and student motivation. Journal of Educational Psychology, 84(3), 261-271.

Ames, C., \& Ames, R. (1981). Competitive versus individualistic goal structures: The salience of past performance information for causal attributions and affect. Journal of Educational Psychology, 73(3), 411.

Ames, C., \& Archer, J. (1988). Achievement goals in the classroom: Student learning strategies and motivation processes. Journal of Educational Psychology, 80, 260-267.

Archer, J. (1994). Achievement goals as a measure of motivation in university students. Contemporary Educational Psychology, 19, 430-446. 
Beckwith, J. B. (1991). Approaches to learning, their context and relationship to assessment performance. Higher education, 22(1), 17-30.

Biggs, J. (1999). Teaching for quality learning at university. London: Open University Press.

Biggs, J., Kember, D., \& Leung, D. Y. P. (2001). The revised two-factor study process questionnaire: RSPQ2F. British Journal of Educational Psychology, 71, 133-149.

Biyikli, C. (2016). The relationship between university students' approaches to learning and their time spared for studying. Inönü University Journal of Faculty of Education 17(3), 98-119. DOI: 10.17679/iuefd.17345407

Blankert T. \& Hamstra M.R. (2017). Imagining success: Multiple achievement goals and the effectiveness of imagery. Basic and Applied Social Psychology 39, 60-67.

Bulus, M. (2011). Goal orientations, locus of control and academic achievement in prospective teachers: an individual differences perspective. Educational Sciences: Theory and Practice, 11(2), 540-546.

Cano, F. (2005). Epistemic beliefs and approaches to learning: Their change through middle school and their influence on academic performance. British Journal of Educational Psychology, 75, 203-221.

Cano, F., \& Berbén, A. B. G. (2009). University students' achievement goals and approaches to learning in mathematics. British Journal of Educational Psychology, 79(1), 131153.

Cetin, B., İlhan, M. \& Yilmaz, F. (2014). An investigation of the relationship between the fear of receiving negative criticism and of taking academic risk through canonical correlation analysis. Educational Sciences: Theory and Practice, 14(1), 146-158. doi: 10.12738/estp.2014.1.1616

Chan, D.W. (2008). Goal orientations and achievement among Chinese gifted students in Hong Kong. High Ability Studies, 19(1), 37-51.

Chan, K. W. (2003). Hong Kong teacher education students' epistemic beliefs and approaches to learning. Research in Education, 69, 36-50.

Chen, A. (2001). A theoretical conceptualization for motivation research in physical education: An integrated perspective. Quest, 53, 35-38.

Church, M., Elliot, A..J. \& Gable, S. (2001). Perceptions of classroom environment, achievement goals, and achievement outcomes. Journal of Educational Psychology, 93, 43-54.

Cuthbert, P. F. (2005). The student learning process: learning styles or learning approaches. Teaching in Higher education, 10(2), 235-249.

Dinç, E., \& Üztemur, S. (2017). Investigating student teachers' conceptions of social studies through the multi-dimensional structure of the epistemological beliefs. Educational Sciences: Theory \& Practice, 17, 2093-2142. http://dx.doi.org/10.12738/estp.2017.6.0429

Diseth, A., \& Kobbeltvedt, T. (2010). A mediation analysis of achievement motives, goals, learning strategies, and academic achievement. British Journal of Educational Psychology, 80, 671-687. doi:10.1348/000709910X492432

Duman, G., \& Eren, A. (2014). Prospective teachers' achievement goals, learning strategies and engagement in lessons: a mediation analysis. Kastamonu Journal of Education, 23(3), 1047-1064.

Dweck. C. S., \& Leggett. E. L. (1988). A social-cognitive approach to motivation and personality. Psychological Review, 95(2), 256-273.

Ekinci, N. (2009). Learning approaches of university students. Education and Science, 34(151), 74-88.

Elliot, A. J. (1999). Approach and avoidance motivation and achievement goals. Educational Psychologist, 34, 169-189 
Elliot A.J. \& Church, M.A. (1997). A hierarchical model of approach and avoidance achievement motivation. Journal of Personality and Social Psychology, 72, 218-232.

Elliot, A. J. \& Harackiewicz, J. M. (1996). Approach and avoidance achievement goals and intrinsic motivation: A mediational analysis. Journal of Personality and Social Psychology, 70, 461-475.

Elliot A. \& McGregor H. (2001). A $2 \times 2$ achievement goal framework. Journal of Personality and Social Psychology, 80, 501-519.

Elliot, A.J., Murayama, K., \& Pekrun, R. (2011). A 3 x 2 achievement goal model. Journal of Educational Psychology, 103, 632-648.

Entwistle, N., \& McCune, V. (2004). The conceptual bases of study strategy inventories. Educational Psychology Review, 16(4), 325-345.

Felder, R. M., \& Brent, R. (2005). Understanding student differences. Journal of Engineering Education, 94(1), 57-72.

Finney, S. J., Pieper, S. L. \& Barron, K. E. (2004). Examining the psychometric properties of the achievement goal questionnaire in a general academic context. Educational and Psychological Measurement, 64, 365-382.

Fraenkel, J. R., Wallen, N. E., \& Hyun, H. H. (2012). How to design and evaluate research in education. (8th edt). New York: McGraw-Hill Humanities/Social Sciences/Languages.

Genc, G. A., \& Goksu, V. (2019). Investigation of high school students' achievement goal orientation and their academic motivation for physic learning in terms of various variables. Mustafa Kemal University Journal of Social Sciences Institute 16(44), 307331.

Gezer, M., \& Sahin, İ. F. (2016). Social studies oriented achievement goal scale (SOAGS): validity and reliability study. Journal of Measurement and Evaluation in Education and Psychology, 7(2), 335-354.

Gezer, M., \& Şahin, İ. F. (2017). Social studies learning approaches scale (SÖYÖ): validity and reliability study. Elementary Online, 16(1).

Gonçalves T., Niemivirta M., \& Lemos M.S. (2017). Identification of students' multiple achievement and social goal profiles and analysis of their stability and adaptability. Learning and Individual Differences, 54, 149-159.

Green, B. A. \& Miller, R. B. (1996). Influences on achievement: goals, perceived ability, and cognitive engagement. Contemporary Educational Psychology, 21(2), 181-192.

Gutman, L.M. (2005). How student and parent goal orientations and classroom goal structures influence the math achievement of African Americans during the high school transition. Personality and Individual Differences, 38(8), 1891-1902.

Heyman, G. D., \& Dweck, C. S. (1992). Achievement goals and intrinsic motivation: Their relation and their role in adaptive motivation. Motivation and Emotion, 16, 231-247.

Ho, I.T. \& Hau, K.T. (2008). Academic achievement in the Chinese context: The role of goals, strategies, and effort. International Journal of Psychology, 43(5), 892-897.

Houghton, W. (2004). Engineering subject centre guide: Learning and teaching theory for engineering academics. Higher Education Academy Engineering Subject Centre, Loughborough University.

Jagacinski, C. M., \& Strickland, O. J. (2000). Task and ego orientation the role of goal orientations in anticipated affective reactions to achievement outcomes. Learning and Individual Difference, 12, 189-208.

Kadioglu-Akbulut, C. K., \& Uzuntiryaki-Kondakci, E. (2019). Turkish adaptation of the $3 \times 2$ goal orientation scale. Bartın University Journal of Faculty of Education, 8(3), 839866.

Kaplan, A. \& Maehr, M. L. (1999). Achievement goals and student well-being. Contemporary Educational Psychology, 24, 330-358. 
Leary, M.R., \& Kowalski, R.M. (1995). Social anxiety. New York: Guilford Publications Inc.

Leenknecht, M., Hompus, P., \& van der Schaaf, M. (2019). Feedback seeking behaviour in higher education: the association with students' goal orientation and deep learning approach. Assessment \& Evaluation in Higher Education, 44(7), 1069-1078.

Limpo, T., \& Alves, R. (2017). Relating beliefs in writing skill malleability to writing performance: The mediating role of achievement goals and self-efficacy. Journal of Writing Research, 9(2), 97-125.

Licht, M. H. (1995). Multiple regression and correlation (Laurence. G. Grimm \& Paul, R. Yarnold) Reading and understanding multivariate statistics. Washington, D.C.: American Psychological Association.

Malhotra, N. K., Kim, S. S., \& Patil, A. (2006). Common method variance in IS research: A comparison of alternative approaches and a reanalysis of past research. Management science, 52(12), 1865-1883.

Marton, F., \& Saljo, R. (1976). On qualitative differences in learning: I-Outcome and process. British Journal of Psychology, 46(4), 4-11.

Matos, L., Lens, W. \& Vansteenkıste, M. (2007). Achievement goals, learning strategies and language among Peruvian high school students. Psychologica Belgica, 47(1), 51-70.

Mayya, S., Rao, A.K. \& Ramnarayan, K. (2004). Learning approaches, learning difficulties and academic performance of undergraduate students of physiotherapy. The Internet Journal of Allied Health Sciences and Practice, 2(4), 1-6.

Middleton, M. J., \& Midgley, C. (1997). Avoiding the demonstration of lack of ability: An underexplored aspect of goal theory. Journal of Educational Psychology, 89, 710-718.

Midgley, C., Middleton, M. \& Kaplan, A. (2001). Performance-approach goals: Good for what, for whom, under what circumstances, and at what cost?. Journal of Educational Psychology, 93, 77-86.

Ozgungor, S. (2014). Relationship between identity statuses and goal orientations based on university students' self-esteem levels. Pamukkale University Journal of Faculty of Education, 35(1), 33-46.

Ozgungor, S., Oral, T. \& Karababa, A. (2015). The role of goal orientations, gender and class in predicting adolescent's life satisfaction. Uludağ University Journal of Faculty of Education 28(1), 75-95.

Pintrich, P. (2000). Multiple goals, multiple pathways: The role of goal orientation in learning and achievement. Journal of Educational Psychology, 92 (3), 544-555.

Pintrich, P. R., Conley, A. M., \& Kempler, T. M. (2003). Current issues in achievement goal theory and research. International Journal of Educational Research, 39, 319-337.

Podsakoff, P.M., Mackenzie, S.B., Podsakoff, N.P. \& Lee, J.-Y. (2003). Common method biases in behavioral research: a critical review of the literature and recommended remedies. Journal of Applied Psychology, 88, 879-903. doi: 10.1037/0021-9010.88.5.879

Ramsden, P. (2003). Learning to teach in higher education (2nd ed.). London and New York: Routledge Farmer.

Rawsthorne, L. J., \& Elliot, A. J. (1999). Achievement goals and intrinsic motivation: A meta-analytic review. Personality and Social Psychology Review, 3(4), 326-344.

Rodríguez, L., \& Cano, F. (2006). The epistemological beliefs, learning approaches and study orchestrations of university students. Studies in Higher Education, 31(5), 617-636.

Schumacker, R. E., \& Lomax, R. G. (2010). A beginner's guide to structural equation modeling. New York: Routledge.

Seifert, T. L. (1995). Academic goals and emotions: A test of two models. The Journal of Psychology, 129, 543-552. 
Senko C., Hulleman C.S., \& Harackiewicz J.M. (2011). Achievement goal theory at the crossroads: Old controversies, current challenges, and new directions. Educational Psychologist 46, 26-47.

Tabachnick, B. G., \& Fidell, L. S. (2013). Using multivariate statistics (6th ed.). Pearson Education, Inc.

Trochim, W. M., \& Donnelly, J. P. (2006). The research methods knowledge base (3. bs.). Cincinnati, $\mathrm{OH}$ : Atomic Dog.

Tuominen-Soini, H., Salmela-Aro, K. \& Niemivirta, M., (2008). Achievement goal orientations and subjective well-being: A person-centered analysis. Learning and Instruction, 18, 251-266.

Üztemur, S., Dinç, E., \& Acun, I. (2020). The relationships amongst middle school students' social studies-oriented epistemic beliefs, learning approaches, academic risk taking behaviors and their course success: A structural equation modeling. Hacettepe University Journal of Education, 35(1), 179-199.doi: 10.16986/HUJE.2019049985

Vrugt, A., \& Oort, F. J. (2008). Metacognition, achievement goals, study strategies and academic achievement: pathways to achievement. Metacognition and Learning, 3(2), 123-146.

Vandewalle, D. (1997). Development and validation of a work domain goal orientation instrument. Educational and Psychological Measurement, 57(6), 9951015. https://doi.org/10.1177/0013164497057006009

Weeks, J. W., Rodebaugh, T. L., Heimberg, R. G., Norton, P. J., \& Jakatdar, T. A. (2009). To avoid evaluation, withdraw: Fears of evaluation and depressive cognitions lead to social anxiety and submissive withdrawal. Cognitive Therapy and Research, 33(4), 375-389. https://doi.org/10.1007/s10608-008-9203-0

Wolters, C., Yu, S. \& Pintrich, P. (1996). The relation between goal orientation and students' motivational beliefs and self-regulated learning. Learning and Individual Differences, 8, 211-238.

Zhou, M. Adesope O.O., Winne P.H., \& Nesbit J.C. (2019). Relations of multivariate goal profiles to motivation, epistemic beliefs and achievement. Journal of Pacific Rim Psychology, 13, e1. https://doi.org/10.1017/prp.2018.28 